\title{
In vitro cytotoxic activity of rhizome extracts of Cyperus rotundus (L.) against colon carcinoma and Ehrlich ascites carcinoma
}

\author{
Hema Nidugala $^{1 *}$, Ramakrishna Avadhani ${ }^{1}$, Ashwini Prabhu ${ }^{2}$, Ravishankar Basavaiah ${ }^{3}$ \\ ${ }^{1}$ Department of Anatomy, Yenepoya Medical College, Yenepoya University, Mangalore, India. ${ }^{2}$ Yenepoya Research Centre, Yenepoya University, \\ Mangalore, India. ${ }^{3}$ SDM Centre for Research in Ayurveda and Allied Sciences, Udupi, India.
}

\begin{tabular}{|c|c|}
\hline ARTICLE INFO & ABSTRACT \\
\hline $\begin{array}{l}\text { Article history: } \\
\text { Received on: } 29 / 08 / 2016 \\
\text { Revised on: } 18 / 09 / 2016 \\
\text { Accepted on: } 24 / 09 / 2016 \\
\text { Available online: } 29 / 11 / 2016\end{array}$ & $\begin{array}{l}\text { Cyperus rotundus (L.) is a perennial herb belonging to family Cyperaceae having tremendous medicinal } \\
\text { properties and it has been used in various formulations of Indian system of medicine. This study was designed to } \\
\text { investigate the in vitro anticancer potential of aqueous and ethanol extracts of Cyperus rotundus (L.). The } \\
\text { cytotoxicity was assessed using SRB Assay and Trypan blue assay against human colon cancer cell line (HCT- }- \\
\text { 116) and Ehrlich Ascites Carcinoma (EAC) cell lines. Results of SRB assay on HCT-116 cells indicated an IC } 50\end{array}$ \\
\hline $\begin{array}{l}\text { Key words: } \\
\text { Cyperus rotundus, } \\
\text { Anticancer activity, SRB } \\
\text { Assay, Trypan Blue assay, } \\
\text { EAC, Colon cancer. }\end{array}$ & $\begin{array}{l}\text { values of } 2158.63 \mu \mathrm{g} / \mathrm{ml} \text { and } 160.19 \mu \mathrm{g} / \mathrm{ml} \text { were obtained for aqueous and ethanol extracts respectively on EAC } \\
\text { cells. Positive control Doxorubicin exhibited } \mathrm{IC}_{50} \text { of } 11.221 \mu \mathrm{g} / \mathrm{ml} \text { and } 23.325 \mu \mathrm{g} / \mathrm{ml} \text { against HCT-116 and EAC } \\
\text { cells respectively. Findings from this study prospect the possible use of C. rotundus as a potential source of } \\
\text { anticancer agent. }\end{array}$ \\
\hline
\end{tabular}

\section{INTRODUCTION}

Cancer is the second most leading cause of death while heart disease being the first in the world (Jemal et al., 2007). Cancer accounted for 8.2 million deaths in 2012. Nearly $30 \%$ of deaths from cancer are due to high body mass index, low intake of fruits and vegetables, lack of physical activity, use of tobacco/alcohol and environmental effects. In developing countries, mortality rates are higher due to lack of healthcare facility and greater exposure to carcinogens 2012 (Steliarova et $a l ., 2012$ ). Despite good progress in the diagnosis and treatment for cancer, it is a major threat accounting for $23 \%$ of the deaths in the USA and $7 \%$ deaths in our country (American Cancer Society, 2015). Existing therapeutic modalities pose a magnitude of side effects, thereby inculcating the need for search of alternative therapies. Herbal medicine plays a vital role in traditional method of healing worldwide against cancer. Plant products, due to their antioxidant property can modulate the physiology as well as metabolism effectively to significantly

* Corresponding Author

Email:hemaumesh77@gmail.com reduce the amount of free radicals and reactive oxygen species generated in tumor microenvironment. Due to the medicinal property of phytochemicals, they are used during or after the cancer therapy treatment to neutralize damage and harmful consequences due to cancer therapies. Use of phytochemicals has long-term health benefits; however, they are used in parallel to the cancer therapy because cancer therapy can cause significant damage to the tumor cells within a short period of time (Eva et al., 2006). Cyperus rotundus, commonly known as Musta, is a medicinal plant belongs to family Cyperaceae. In Indian system of medicine, its rhizomes are used in the treatment of several clinical conditions like candidiasis, diabetes, diarrhea, malaria, dysmenorrhea and menstrual irregularities (Sivapalan et al., 2013). Its oil extracts are widely used in ancient medicine for various kinds of health problems like stomach problem, constipation, fever, tooth problems and digestive disorders antispasmodic and menstrual irregularities (Puratchikody et al., 2006). Whole plant and closer view of the rhizome is presented in Fig. 1. Proposed study was designed to investigate the in vitro cytotoxic potential of aqueous and ethanol extracts of Cyperus rotundus (L.) against colon cancer and EAC cells. 


\section{MATERIALS AND METHODS}

\section{Collection and identification of the herb}

Dried rhizomes of C.rotundus were collected from a local Ayurvedic pharmacy in Mangalore, Karnataka, India. The plant material was authenticated by Dr. Sunil Kumar, Senior Research officer, Department of Pharmacognosy, SDM Centre for Research in Ayurveda and Allied Sciences, Udupi and voucher specimen (No.11110101) was deposited in the plant repository of SDM Research Center. The shade dried rhizomes of the $C$. rotundus were coarsely powdered and preserved at $-20^{\circ} \mathrm{C}$ for further studies.

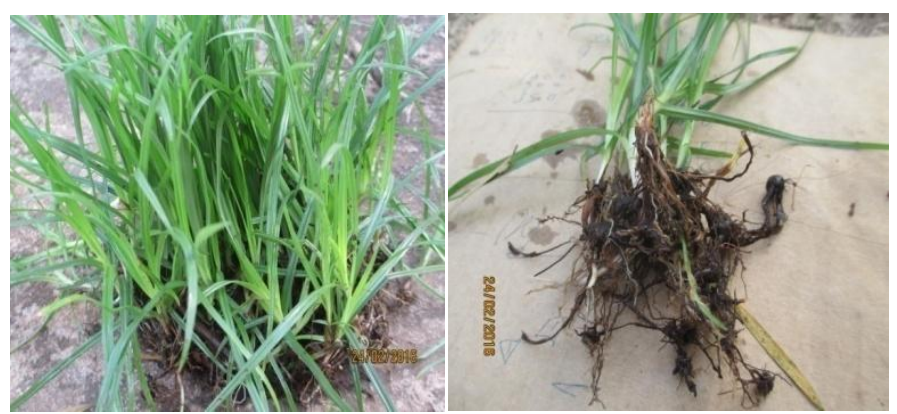

Fig. 1: Cyperus rotundus. A: Whole plant; B: Closer view of rhizome.

\section{Preparation of extracts}

Ethanol and aqueous extracts of $C$. rotundus were prepared as per the standard procedures (Raman, 2006).

\section{Cell lines and culture conditions}

Human colon cancer cell line (HCT-116) was procured from National Centre for Cell Sciences, Pune. Ehrlich's Ascites carcinoma (EAC) were obtained from Amala Cancer Research Center, Amala Nagar, Thrissur, Kerala, India. The cells were maintained as ascites tumor in Swiss albino mice by i.p. inoculation.

Dulbecco's modified eagles media (DMEM), RPMI1640, fetal bovine serum (FBS) and SRB reagent were procured from Sigma Aldrich, USA. HCT-116 cells were cultured in DMEM supplemented with $10 \%$ FBS and $1 \%$ antibiotic solution. EAC cells were cultured in RPMI-1640 supplemented with $10 \%$ FBS. Cells were maintained at $37^{\circ} \mathrm{C}$ and $5 \% \mathrm{CO}_{2}$ in a humidified atmosphere. They were used for the experiments after three consecutive passages.

\section{Sulphorhodamine-B (SRB) assay}

HCT-116 and EAC cells were seeded onto 96 well flat bottom microtiter plates at a seeding density of $5 \times 10^{3}$ cells in 0.1 $\mathrm{ml}$ of DMEM medium supplemented with $10 \%$ FBS and allowed to attach for $24 \mathrm{~h}$. Test compounds were prepared just prior to the experiment and serially diluted with medium to get the working stock of 200, 100, 50 and $25 \mu \mathrm{g} / \mathrm{ml}$ concentration. After $24 \mathrm{hrs}$ of incubation, cells were treated with $100 \mu \mathrm{l}$ of test solutions at different concentrations and further incubated for $48 \mathrm{~h}$. Cells in the control group received medium only containing $0.5,0.25 \%$
DMSO. Each treatment was performed in triplicates. After the treatment duration, drug containing media was removed and washed with $200 \mu \mathrm{l}$ of PBS.50 $\mu \mathrm{l}$ of $30 \%$ TCA was added to fix the cells and kept at $4^{0} \mathrm{C}$ for $1 \mathrm{~h}$, following which each well was gently washed with sterile water to remove TCA, medium and dead cells. Plate was allowed to air dry and $50 \mu 1$ of $0.05 \%$ SRB dye solution was added and incubated at room temperature in dark for $30 \mathrm{~min}$.After $30 \mathrm{~min}$, unbound SRB was removed by washing with $200 \mu \mathrm{l}$ of $1 \% \mathrm{v} / \mathrm{v}$ acetic acid. The plate was air dried and 200 $\mu l$ of trizma base buffer was added to each well to dissolve the cell bound dye.The plate was shaken for $20 \mathrm{~min}$ on a gyratory shaker and the optical density was recorded at $540 \mathrm{~nm}$ with reference wavelength of $630 \mathrm{~nm}$ in an ELISA plate reader. Percentage cell viability was calculated. Values were represented as Mean \pm SEM. O.D values (proportional to cell death) were plotted against the tested drug concentrations.

\section{Trypan blue exclusion assay}

Stock cell suspension at a density of $1 \times 10^{7}$ was made in PBS, from which $100 \mu \mathrm{l}$ of suspension was taken in sterile test tubes. The cells were treated with $100 \mu \mathrm{l}$ of test drugs of varying concentrations (not more than $0.1 \%$ DMSO) and $700 \mu \mathrm{l}$ of PBS was added. Cells were incubated at $37^{\circ} \mathrm{C}$ for $3 \mathrm{~h}$. After the exposure $100 \mu \mathrm{l}$ of trypan blue was added and mixed well. Total numbers of dead and viable cells in all the four corner squares of the chamber were counted using a haemocytometer and the percentage viability was calculated as follows:

$\%$ viable cells $=($ Number of unstained cells/Total number of cells $)$ $\mathrm{x} 100$

\section{Statistical Analysis}

All data were presented as Mean \pm SEM. The significance of intergroup differences was evaluated by one-way ANOVA followed by Dunnett's t-test using Graph Pad Prism version 5.0. Statistical differences were considered significant at $\mathrm{p}$ $<0.05$.

\section{RESULTS AND DISCUSSION}

Evaluation of anticancer activity of $C$. rotundus extract by SRB assay revealed that ethanol extract possessed potent anticancer activity with an $\mathrm{IC}_{50}$ value of $72.06 \mu \mathrm{g} / \mathrm{ml}$ on HCT-116 cells after $48 \mathrm{~h}$ of exposure (Fig. 2). The standard used was Doxorubicin which showed an $\mathrm{IC}_{50}$ value of $11.221 \mu \mathrm{g} / \mathrm{ml}$.

Fig. 3 depicts the in vitro cytotoxic effect of aqueous and ethanol extracts of $C$. rotundus on EAC cell line by Trypan blue dye exclusion assay. $\mathrm{IC}_{50}$ value was found to be 2158.653 and $160.190 \mu \mathrm{g} / \mathrm{ml}$ for aqueous and ethanol extracts respectively. The standard drug Doxorubicin showed an $\mathrm{IC}_{50}$ value of $23.375 \mu \mathrm{g} / \mathrm{ml}$.

The present investigation showed that ethanol extract of C. rotundus acted as a potential cytotoxic agent on both colon carcinoma and EAC. Several phytochemicals from natural sources have been effectively used for the treatment of cancer. Among the arena of phytochemicals which are under clinical trials to be used 
as alternatives to chemopreventive agents, apigenin from parsley, curcumin from turmeric, crocetin from saffron, cyanidins and resveratrol from grapes, diindolylmethane (DIM) from Brassica vegetables, epigallocatechin gallate from green tea, fisetin from strawberries and apples, genistein from soybean, gingerol from gingers, kaempferol from tea and broccoli, lycopene from tomato, phenyl isothiocyanate and sulforaphane from cruciferous vegetables, rosmarinic acid from rosemary, triterpenoids from wax-like coatings of fruits and medicinal herbs, Vitamin D from mushroom and Vitamin $\mathrm{E}$ from plant oil are the major ones (Nirmala et al., 2011; Liu, 2004; Solanki, 2004). Phytochemical screening of both extracts indicated the presence of coumarins, carbohydrates, steroids, phenols and saponins. In ethanol extract, terpinoids and tannins were also present.

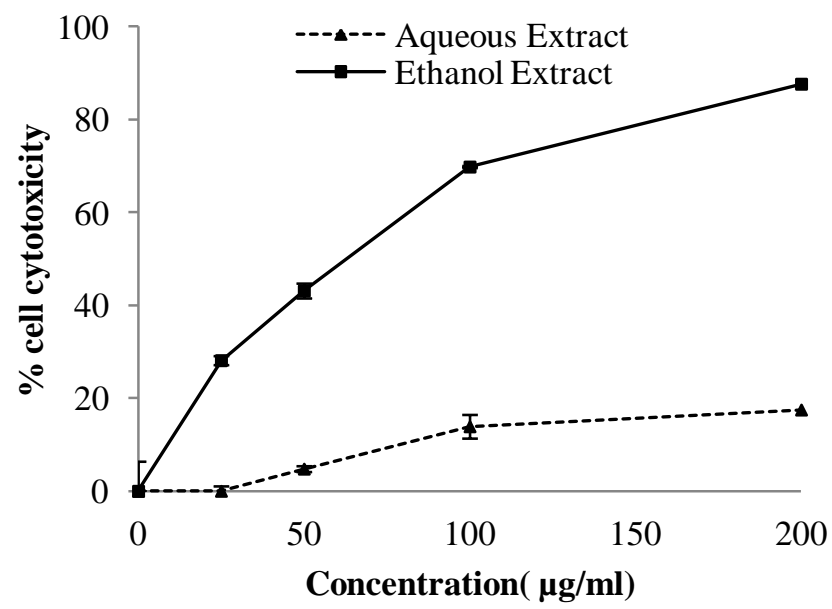

Fig. 2: In vitro cytotoxic effect of aqueous and ethanol extracts of $C$. rotundus on HCT 116 cells by SRB assay.

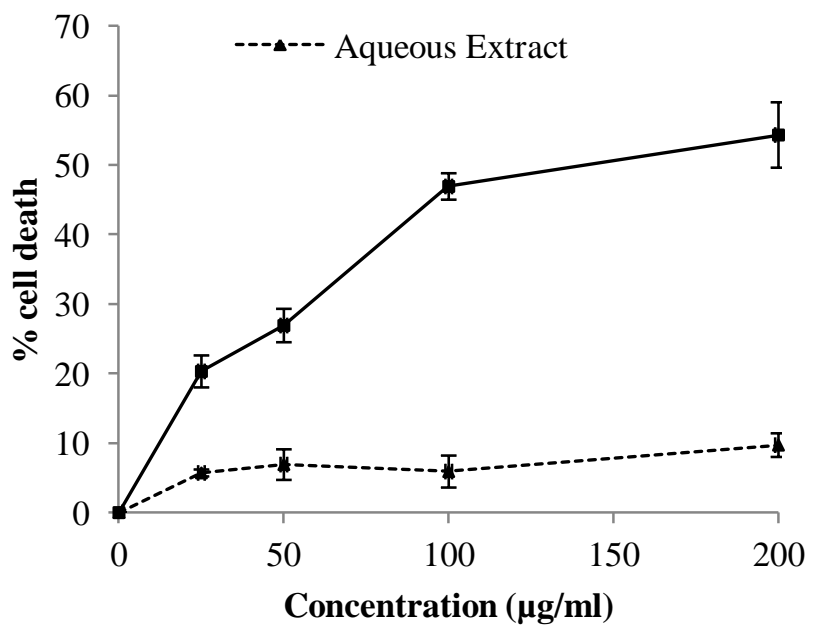

Fig. 3: In vitro cytotoxic effect of aqueous and ethanol extracts of $C$. rotundus on EAC cell line by Trypan blue dye exclusion assay

Cyperus rotundus, a perennial grass, has long been used as herbal medicine for several diseases and health problems due to its anti-microbial, anti-malarial and anti-spasmodic properties (Zhu et al., 1997; Bhattarai, 1993; Uddin et al., 2006). Essential oils, flavonoids, terpenoids, mono and sesquiterpenes of Cyperus were recently found to have significant antioxidant, free-radical scavenging activity and showed inhibitory action against lipid peroxidation, protein oxidation and glycoxidation (Yazdanparast and Ardestani, 2007). Extracts from C. rotundus showing antimutagenic and radical scavenging activities against aflatoxin B1 and sodium azide were also reported (Kilani et al., 2005). A recent study proved cytotoxic and anti-apoptotic activity of C.rotundus tuber extract in murine leukemic cell lines L1210 (Kilani et al., 2008). Findings for this investigation prospect $C$. rotundus ethanol extractives as a potential anticancer agent after pre-clinical and clinical investigations.

\section{CONCLUSION}

This study provides the cytotoxic activity of rhizome extract of $C$. rotundus. The anticancer activity of C. rotundus ethanol extract was higher than that of the aqueous extract, thereby indicating its possible usage as a potential source of cancer therapeutic. Active principles from $C$. rotundus ethanol extract can be used as ingredients of anticancer formulations.

\section{ACKNOWLEDGEMENT}

Authors are grateful to Yenepoya University and Manipal University for giving permission to carry out this study. Authors are thankful to Dr. Mallikarjuna Rao and Dr. Nitesh Kumar from Manipal College of Pharmaceutical Sciences for their kind support.

\section{Financial support and sponsorship: Nil}

Conflict of Interests: There are no conflicts of interest.

\section{REFERENCES}

American Cancer Society. Cancer Facts \& Figures 2015. Atlanta: American Cancer Society; 2015.

Bhattarai NK. Folk herbal remedies for diarrhoea and dysentery in central Neptal. Fitoterapia, 1993; 64: 243-250.

Feinberg AP, Ohlsson R, Henikoff S. The epigenetic progenitor origin of human cancer. Nat Rev Genet, 2006; 7:21-33.

Jemal A, Siegel R, Ward E, Murray T, Xu J, Thun MJ. Cancer statistics. CA Cancer J Clin, 2007; 57: 43-66.

Kilani S, Ben Sghaier M, Limem I, Bouhlel I, Boubaker J, Bhouri W, Chekir-Ghedira L. In vitro evaluation of antibacterial, antioxidant, cytotoxic and apoptotic activities of the tubers infusion and extracts of Cyperus rotundus. Bioresour. Technol, 2008; 99:9004-9008. http://doi.org/10.1016/j.biortech.2008.04.066.

Nirmala MJ, Samundeeswari A, Deepa Sankar P. Natural plant resources in anti-cancer therapy-A review. Res Plant Biol, 2011; 1: 01-14.

Puratchikody A, Nithya C, Nagalakshmi G. Wound healing activity of Cyperus rotundus Linn. Indian J Pharm Sci, 2006; 68: 97-101.

Raaman N. Phytochemical Techniques. New India Publishing Agency, New Delhi. 2006; 9-18.

Rui Hai Liu. Potential Synergy of Phytochemicals in Cancer Prevention: Mechanism of Action. American Society for Nutritional Sciences. International Research Conference on Food, Nutrition, and Cancer 2004; 3479S -3485S.

Sivapalan SR. Medicinal uses and pharmacological activities of Cyperus rotundus Linn: A review. Int J Sci Res Pub, 2013; 3:1-8. 
Solanki R. Composition of eleven herbals for treating cancer. U.S. Patent No. 6,780,441; 24 Aug. 2004.

Steliarova-Foucher E, O'Callaghan M, Ferlay J, Masuyer E, Comber H, Bray F. European cancer observatory: cancer incidence, mortality, prevalence and survival in Europe. Version1.0 (September 2012) European Network of Cancer Registries, International Agency for Research on Cancer. Available from: http://eco.iarc.fr [accessed 14/09/201]

Uddin SJ, Mondal K, Shilpi JA, Rahnan MT. Antidiarrhoeal activity of Cyperus rotundus. Fitoterapia, 2006; 77: 134-136.

Yazdanparast R, Ardestani A. In vitro antioxidant and free radical scavenging activity of Cyperus rotundus. J Med Food, 2007; 10: 667-674.

Zhu M, Luk HH, Fung HS, Luk CT. Cytoprotective effects of Cyperus rotundus against ethanol induced gastric ulceration in rats. Phytother. Res, 1997; 11: 392-394.

\section{How to cite this article:}

Nidugala H, Avadhani R, Prabhu A, Basaviah R. In vitro cytotoxic activity of rhizome extracts of Cyperus rotundus (L.) against colon carcinoma and Ehrlich ascites carcinoma. J App Pharm Sci, 2016; 6 (11): $172-175$. 